\title{
Two new species of the genus Hemiancistrus Bleeker (Teleostei: Siluriformes: Loricariidae) from the upper rio Uruguai basin
}

\author{
Alexandre Rodrigues Cardoso and José Francisco Pezzi da Silva
}

Two new species of Hemiancistrus are described: Hemiancistrus votouro n. sp. and Hemiancistrus meizospilos n. sp. from upper rio Uruguai basin. They differ from their congeners except H. chlorostictus, H. megacephalus, and H. macrops by the presence of light dots on fins and lateral and dorsal portions of head and body. Hemiancistrus votouro and H. meizospilos differ from the species above by meristic and morphometric data and by the color pattern.

Duas novas espécies de Hemiancistrus são descritas: Hemiancistrus votouro e Hemiancistrus meizospilos da bacia do rio Uruguai superior. Elas diferem dos seus congêneres, exceto de H. chlorostictus, H. megacephalus e H. macrops, pela presença de pontos claros distribuídos nas nadadeiras e nas porções laterais e dorsal da cabeça e do corpo. Hemiancistrus votouro e H. meizospilos diferem das espécies citadas acima por dados merísticos e morfométricos e pelo padrão de colorido.

Keywords: Neotropical, catfish, Ancistrinae, Hemiancistrus chlorostictus.

\section{Introduction}

Hemiancistrus Bleeker is a loricariid genus with 17 valid species (Cardoso \& Lucinda, 2003; Fisch-Muller, 2003). Hemiancistrus ranges from Panama, in Central America, to southern Brazil. In southern Brazil the genus was first recorded in the upper rio Uruguai basin by Bertoletti et al. (1989), and in the laguna dos Patos by Malabarba (1989). Cardoso \& Malabarba (1999) described three new species of Hemiancistrus: $H$. chlorostictus and H. fuliginosus from the rio Uruguai basin, and $H$. punctulatus from the laguna dos Patos system. Recent collecting efforts in the rio Uruguai basin revealed two undescribed species with a color pattern similar to that of H. chlorostictus, demonstrating that Hemiancistrus diversity in southern Brazil is higher than previously thought. A clear diagnosis of the genus Hemiancistrus is lacking, and the proposal of a diagnosis for this genus depends on the taxonomic revisions of other ancistrine genera, and on a phylogenetic study encompassing various ancistrine representatives. This goes beyond the scope of this paper. Additionally, there has been much discussion concerning the definition of the genus and its distinctiveness from Peckoltia
Ribeiro (see Cardoso \& Lucinda, 2003 for details). We have tentatively chosen to assign the new species to Hemiancistrus due to reasons exposed by Cardoso \& Lucinda (2003).

\section{Material and Methods}

Measurements and counts follow Cardoso \& Lucinda (2003). Additional measurements are: adipose spine length (measured from its origin to its distal tip), caudal peduncle length (measured from anal-fin origin to last plate of medium series) and length of exposed portion of cleithrum (measured from its anterior to its posterior margin). Examined specimens belong to Museu de Ciências e Tecnologia, Pontifícia Universidade Católica do Rio Grande do Sul, Porto Alegre (MCP) and Museu Nacional, Rio de Janeiro (MNRJ). Comparative material is listed in Cardoso \& Malabarba (1999) and Cardoso \& Lucinda (2003). Morphometric distances were explored through the Principal Components Analysis (PCA) on the covariance matrix of log-transformed measurements to assess morphometric variations between species. The logarithmic transformation preserves allometries, produces a covariance matrix independent of scaling differences (Jolicoeur, 
1963), and allows the characterization of relative growth rates with respect to general body size (Bookstein et al., 1985). PCA analyses were performed using the software PAST (Ryan et al., 1995). Factor scores were plotted in the SigmaPlot software (Brannan et al., 2000). The ANCOVA test was run using SPSS (version 10.0).

\section{Results}

\section{Hemiancistrus votouro, new species}

Fig. 1

Holotype. MCP 33594, 133.9 mm SL (female); Brazil: Rio Grande do Sul: Benjamin Constant: arroio Lageado Grande (tributary of the rio Passo Fundo, rio Uruguai basin), ca. $2.5 \mathrm{~km} \mathrm{NE}$ from Votouro Indian Reserve (27²6’ 50"S 52³7' $\left.5^{\prime \prime} \mathrm{W}\right)$, W. Bruschi Jr. \& J. F. P. da Silva, 1 May 2002.

Paratypes. MCP 29661, 99.5-141.2 mm SL (3 males and 2 females); MNRJ 25920, 99.5-136.3 mm SL (1 male and 1 female), collected with the holotype.

Diagnosis. Hemiancistrus votouro differs from all other Hemiancistrus except $H$. chlorostictus, $H$. meizospilos, $H$. megacephalus, and $H$. macrops by the presence of light dots on all fins and the lateral and dorsal portions of body. Hemiancistrus votouro differs from $H$. chlorostictus by the number of premaxillary teeth (61-79 vs. 30-54), by the larger adipose-fin spine (9.0-10.4\% SL vs. 5.8-8.0\% SL; Fig. 2), by the deeper caudal peduncle (11.0-11.8\% SL vs. 9.6-10.4\% SL), by the larger pectoral fin (36.2-41.3\% SL vs. 30.6-35.4\% SL), by the larger exposed portion of cleithrum (11.2-12.7\% SL vs. 9.3-10.6\% SL; Fig. 3), by the narrower body at dorsal-fin origin (17.9-19.8\% SL vs. 19.9-25.3\% SL) and first anal-fin pterygiophore not exposed (vs. exposed). Hemiancistrus votouro is distinguished from $H$. meizospilos by the smaller orbit diameter (14.5-16.7\% HL vs.16.7-21.0\% HL; Fig. 4) and by the much smaller light markings (one to three dots per plate $v s$. one large dot occupying one to three plates and skin between them). Hemiancistrus votouro differs from $H$. megacephalus and $H$. macrops by the number of the light markings per body plate (one to three small dots per plate $v s$. only one large dot on each body plate).

Description. Meristic and proportional measurements in Table 1. Dorsal profile of body gently arched from snout tip to dorsalfin origin. Body narrowing progressively caudally from cleithrum. Trunk mostly straight and tapering slightly to caudal-fin base. Trunk and caudal peduncle mostly rounded in cross section, slightly flattened ventrally, more compressed caudally. Ventral surface flattened. Head slightly concave between orbits; dermal plates not carinate; upper margin of orbits (dorsolateral margin of frontal and sphenotic bones) slightly elevated. Snout broad and rounded anteriorly, slightly concave anterior to nares.

Odontodes not forming keels on lateral plates. Dorsal, supramedial, median, and inframedial plate rows complete from head to caudal fin. Abdomen without platelets, except for small patch of platelets between pectoral fins. Cheek plates present on lateral margins of head; snout plates reduced to few granular platelets, absent in rectangular area on snout tip; five rows of plates on caudal peduncle; 25-26 plates in medial plate row. Nuptial males with hypertrophied odontodes slightly larger on tip of pectoralfin spine. Cheek plates evertible with 13-24 hypertrophied odontodes with curved tips, longest odontode one and half times eye diameter (juveniles with fewer and shorter odontodes than adults). Opercle supporting about 15-20 small odontodes in juveniles and adults. Preopercle covered by small platelets.

Eyes small (14.5-16.7\% HL), iris with large dorsal flap. Lips large, occupying most of ventral surface of head. Lower lip mostly covered with papillae, except for smooth band near its border. Maxillary barbel free and pointed, typically reaching about one third of way from its origin to gill opening. Some individuals with one or both barbels bifurcated.

Teeth small, bifid; medial cusp large, blade-like, and slightly rounded; lateral cusp minute, pointed, never reaching more than one third of mesial cusp length. Premaxillary teeth 61 to 79 (mean=71.4). Dentary teeth 61 to 84 (mean=71.8). Upper and lower jaw rami form angles slightly less than $180^{\circ}$.

Dorsal-fin rays II,7; reaching adipose-fin origin when depressed. Dorsal fin originating at vertical line in front of pelvic-fin base; dorsal-fin spinelet V-shaped, locking mechanism functional. Pectoral-fin rays I,6; tip of spine reaching beyond half-length of pelvic-fin origin in both sexes, when depressed. Pelvic-fin rays I,5; tip of spine reaching slightly beyond anal-fin origin when depressed. Anal-fin rays I,4. First anal-fin pterygiophore not exposed. Caudal-fin rays I,14,I; caudal fin slightly truncate. Adipose-fin spine large and thick.

Color in alcohol. Dorsal and lateral surface of body and head dark gray, covered with small light dots, less numerous on caudal peduncle; one to three dots per body plate. Ventral body surface whitish. Fins dark gray with light dots on rays, occasionally also on membranes (Fig.1). Some specimens with light dots almost imperceptible.

Distribution. Known only from type-locality. The arroio Lageado Grande, tributary of the rio Erechim, rio Passo Fundo system (upper rio Uruguai basin), Rio Grande do Sul, Brazil (Fig. 5).

Ecological notes. Type-locality for this species is a $2-5 \mathrm{~m}$ wide stream, with rocky and sandy bottom, small rapids separated by pools and marginal vegetation moderately preserved.

Etymology. The specific name votouro (noun in apposition) is given in honor of the Votouro Indian Reserve, situated on Benjamin Constant, Rio Grande do Sul, Brazil. 


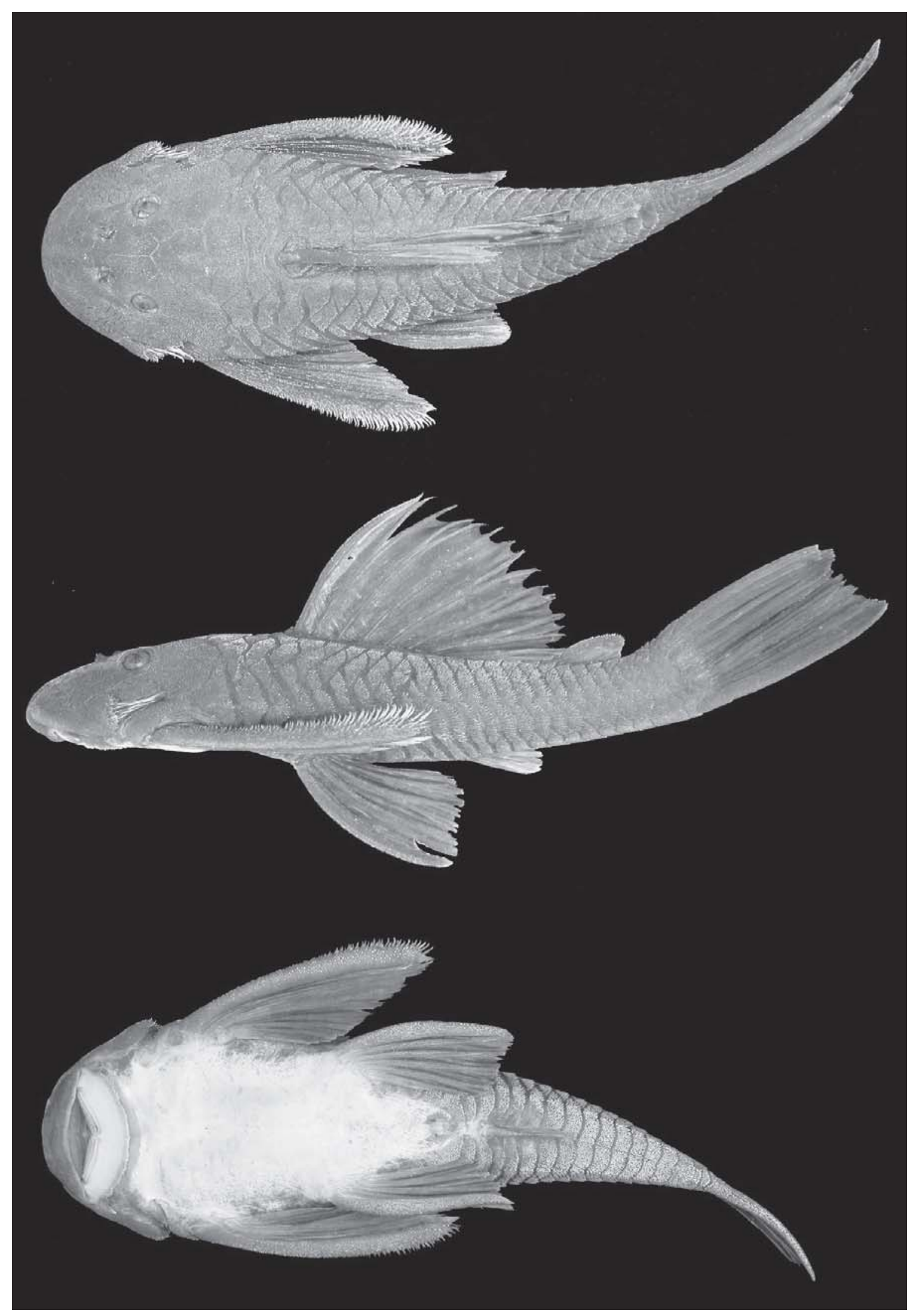

Fig. 1. Hemiancistrus votouro, holotype, MCP 33594, female, $133.9 \mathrm{~mm} \mathrm{SL}$, arroio Lageado Grande, about $2.5 \mathrm{~km}$ NE from Votouro Indian Reserve (tributary of the rio Passo Fundo, rio Uruguai basin), Benjamin Constant, Rio Grande do Sul, Brazil. 


\section{Hemiancistrus meizospilos, new species}

Fig. 6

Holotype. MCP 34091, 148.4 mm SL (male); Brazil: Santa Catarina: Coronel Freitas: rio Chapecó (tributary of the rio Uruguai basin), Leandro Baucke, 20 May 2003.

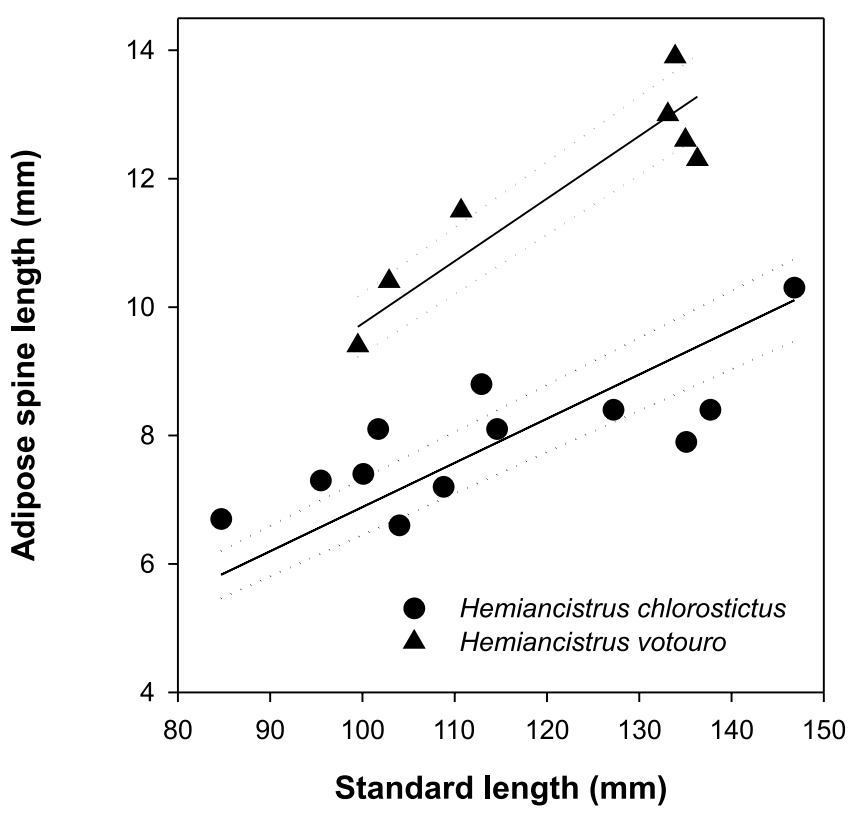

Fig. 2. Scatter plot and regression line of adipose spine length as a function of standard length in Hemiancistrus votouro and $H$. chlorostictus.

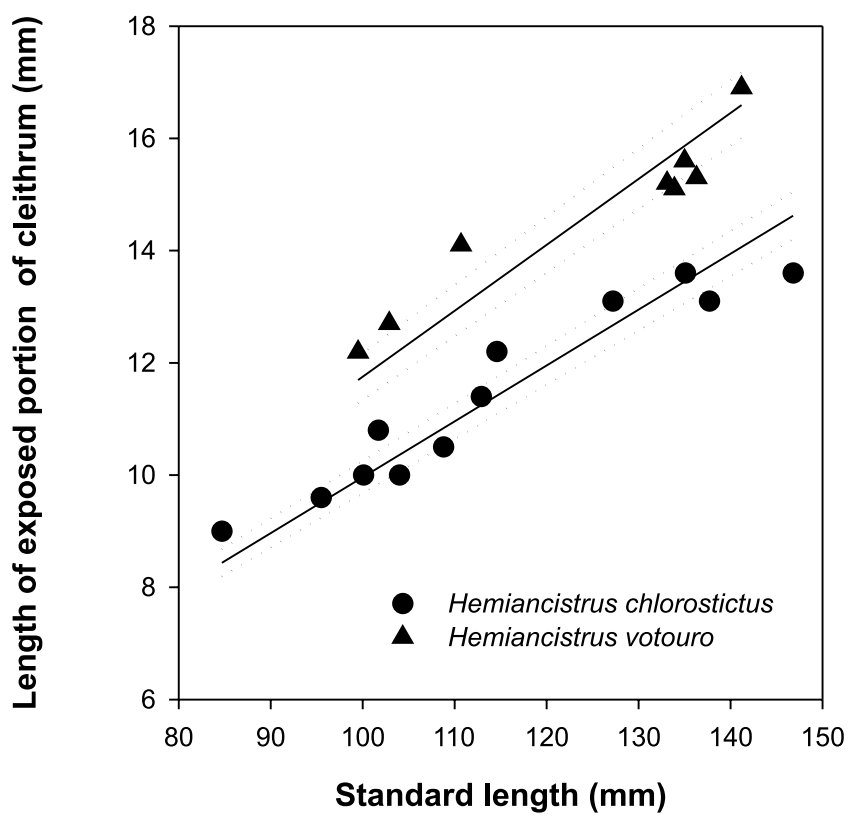

Fig. 3. Scatter plot and regression line of length of exposed portion of cleithrum as a function of standard length in Hemiancistrus votouro and $H$. chlorostictus.
Paratypes. MCP 34092, 72.4-149.1 mm SL (5 males, 14 females and 2 juveniles); MNRJ 25921, 115.2-122.6 mm SL (4 males and 1 female), collected with the holotype. MCP 34093, 119.1 mm SL (1 male); Brazil: Santa Catarina: Formosa do Sul, rio do Ouro (tributary of the rio Chapecó), Alcione Cella, 2003.

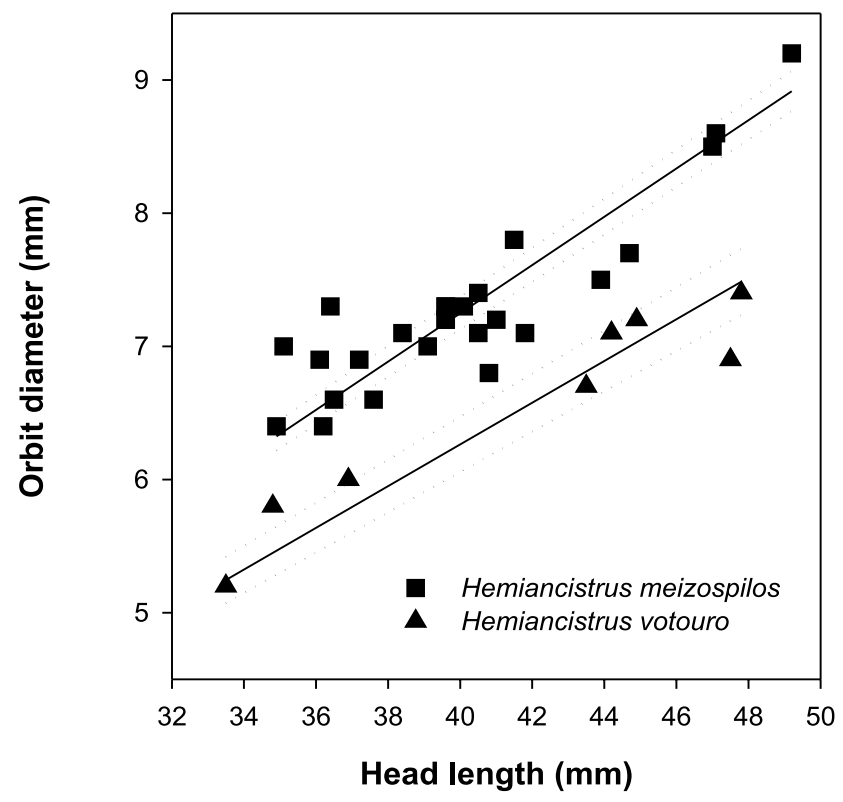

Fig. 4. Scatter plot and regression line of orbit diameter as a function of head length in Hemiancistrus votouro and $H$. meizospilos.

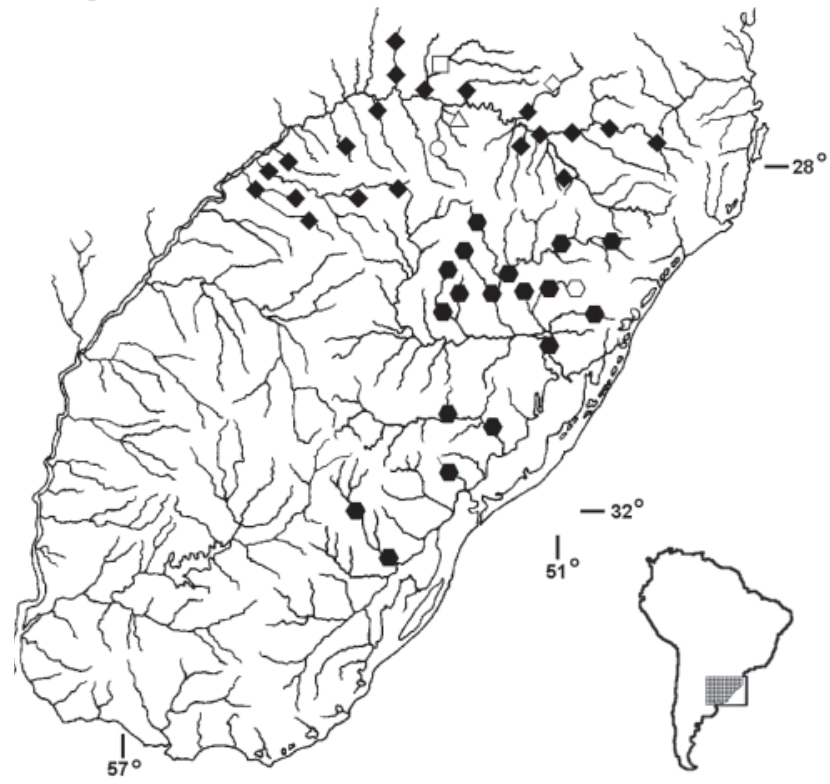

Fig. 5. Collection localities of $H$. votouro (triangle), $H$. meizospilos (square), H. punctulatus (hexagons), $H$. chlorostictus (circle) and H. fuliginosus (lozenges) in Rio Grande do Sul, Brazil, and Uruguay. Some symbols represent more than one lot or locality. Open symbols represent type localities. 


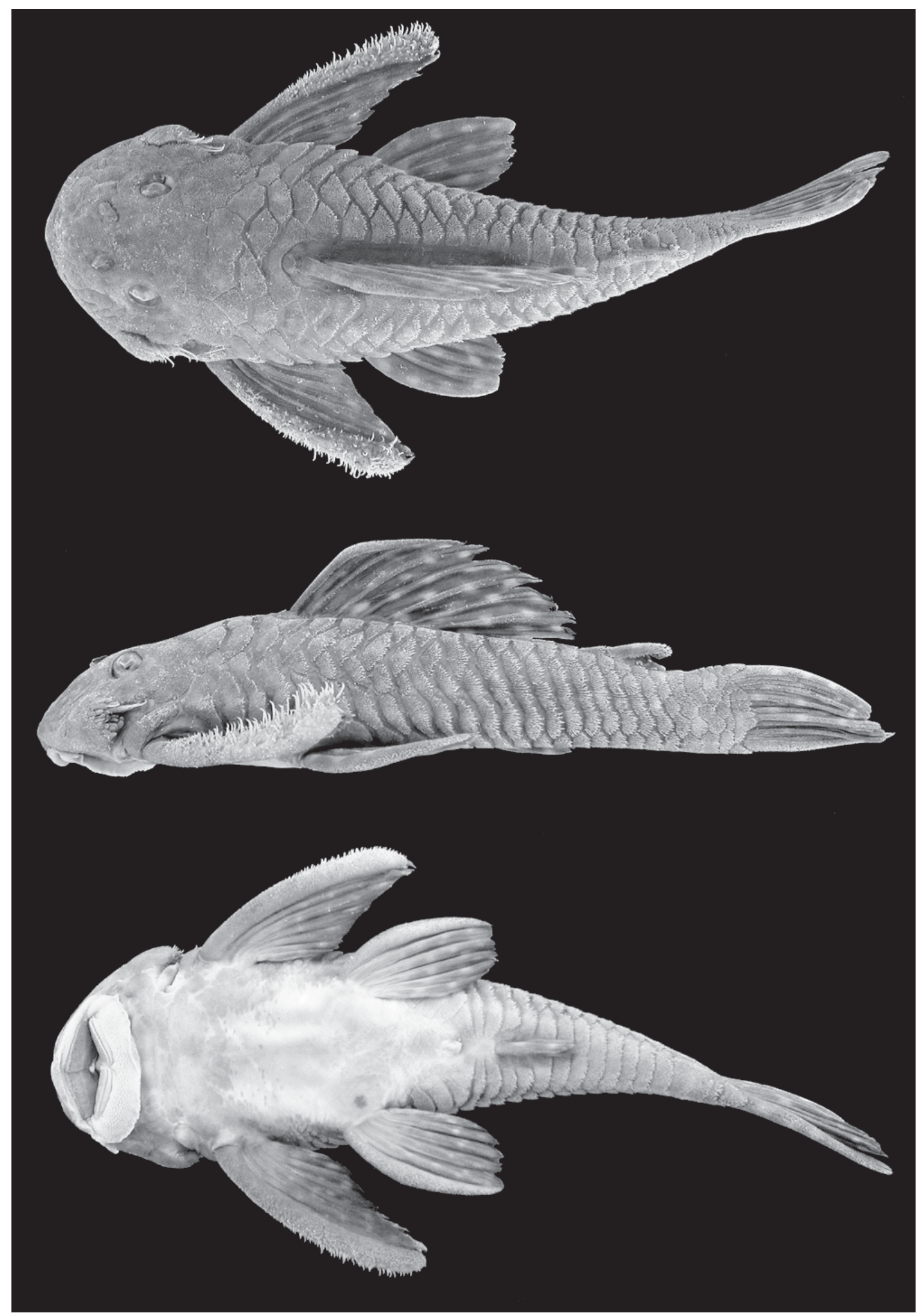

Fig. 6. Hemiancistrus meizospilos, holotype, MCP 34091, male, $148.4 \mathrm{~mm}$ SL, rio Chapecó (tributary of the rio Uruguai basin), Coronel Freitas, Santa Catarina, Brazil. 


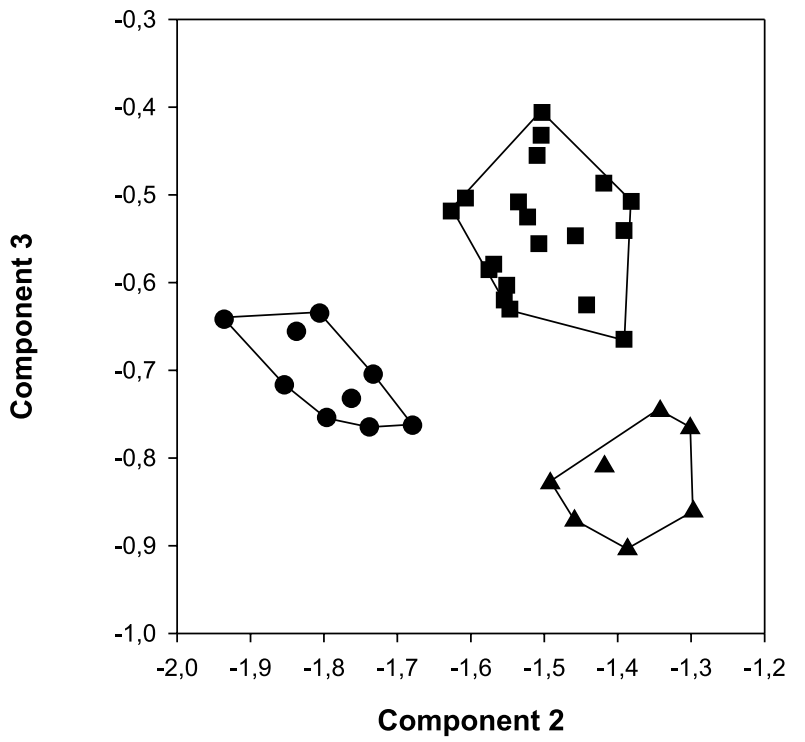

Fig. 7. Principal components analysis on covariance matrix of log-transformed measurements of Hemiancistrus votouro (triangles), H. meizospilos (squares) and H. chlorostictus (circles). Scatter plot of scores on second (PC2) and third principal components (PC3).

Diagnosis. Hemiancistrus meizospilos differs from all other Hemiancistrus except from $H$. chlorostictus, $H$. votouro, $H$. megacephalus, and $H$. macrops by the presence of light dots on all fins and the lateral and dorsal portions of body. Hemiancistrus meizospilos differs from $H$. chlorostictus and $H$. votouro by the much larger light markings (one large dot occupying one to three plates $v s$. one to three dots per plate) and from $H$. votouro by the larger orbit diameter (16.7-21.0\% HL vs. 14.5-16.7\% HL; Fig. 4). Hemiancistrus meizospilos is distinguished from $H$. megacephalus and $H$. macrops by the area that light dots occupying each body plate (one large dot occupying one to three plates and skin between them $v s$. one large dot occupying only one body plate).

Description. Meristic and proportional measurements in Table 1. Dorsal profile of body gently arched from snout tip to dorsalfin origin. Body narrowing progressively caudally from cleithrum. Trunk mostly straight and tapering slightly to caudal-fin base. Trunk and caudal peduncle mostly rounded in cross section, slightly flattened ventrally, more compressed caudally. Ventral surface flattened. Head slightly concave between orbits; dermal plates not carinate; upper margin of orbits (dorsolateral margin of frontal and sphenotic bones) slightly elevated. Snout broad and rounded anteriorly, slightly concave anterior to nares.

Odontodes not forming keels on lateral plates. Dorsal, supramedial, median, and inframedial plate rows complete from head to caudal fin. Abdomen with small patch of platelets between pelvic fins, and with larger patch of platelets between lower lip and area between pelvic fins, abdomen otherwise naked. Narrow band of minute platelets along ventral area between pectoral- and pelvic-fin origins. Cheek plates present on lateral margins of head; snout plates reduced to few granular platelets, absent in rectangular area on snout tip; five rows of plates on caudal peduncle; 25 plates in medial plate row. Nuptial males with hypertrophied odontodes slightly larger on tip of pectoral-fin spine. Cheek plates evertible with 10-15 hypertrophied odontodes with curved tips, longest odontode one and half times eye diameter (juveniles with fewer and shorter odontodes than adults). Opercle supporting about 15-27 small odontodes in juveniles and adults. Preopercle covered by small platelets.

Eyes small (16.7-20.1\% HL), iris with large dorsal flap. Lips large, occupying most of ventral surface of head. Lower lip mostly covered with papillae, except for smooth band near its border. Maxillary barbel free and triangular, typically reaching about one third of way from its origin to gill opening. Some individuals with one or both barbels bifurcated.

Teeth small, bifid; medial cusp large, blade-like, and slightly rounded; lateral cusp minute, pointed, never reaching more than one third of mesial cusp length. Premaxillary teeth 50 to 66 (mean=57.2). Dentary teeth 48 to 67 (mean=58.4). Upper and lower jaw rami form angles slightly less than $180 \mathrm{o}$.

Dorsal-fin rays II, 7; not reaching adipose-fin origin when depressed. Dorsal fin originating at vertical line in front of pelvic-fin base; dorsal-fin spinelet V-shaped, locking mechanism functional. Pectoral-fin rays I,6; tip of spine reaching beyond half-length of pelvic-fin origin in both sexes, when depressed. Pelvic fin rays I,5; tip of spine reaching approximately anal-fin origin when depressed. Anal-fin rays I,4. First anal-fin pterygiophore occasionally exposed in some specimens (not exposed in the holotype). Caudal-fin rays I,14,I; caudal fin slightly truncate. Adipose-fin spine large and thick.

Color in alcohol. Dorsal and lateral surface of body and head dark gray with large light dots; one dot occupying one to three plates and skin between them. Ventral body surface whitish. Fins dark gray with large light dots on rays, and occasionally also on membranes between fin rays (Fig. 6). Juveniles with small light blotches on body.

Distribution. Hemiancistrus meizospilos is only known from its type-locality on the rio Chapecó system, tributary of the rio Uruguai (upper rio Uruguai basin), Santa Catarina, Brazil (Fig. 5).

Etymology. From the Greek adjective meizon (masculine, nominative singular), comparative of megas (big, great), and spilos (dots), alluding to larger size of dots on comparison to smaller size on remaining white-spotted species of southern Brazil.

\section{Discussion}

Among remaining species of Hemiancistrus, only three possess light dots on the lateral and dorsal portions of head 
and body, and plain, spotless ventral surface: Hemiancistrus chlorostictus from rio Passo Fundo (rio Uruguai basin); $H$. megacephalus (Günther) and H. macrops (Lütken), from Suriname. Although, color patterns of southern Brazilian species are composed of one large dot occupying one to three plates and skin between them (H. meizospilos), or one to three small light dots $(H$. votouro and $H$. chlorostictus) distributed on each lateral and dorsal plate of body surface and in all fins, while H. megacephalus and H. macrops have only one large dot on each body plate (Regan, 1904).

Hemiancistrus punctulatus, $H$. fuliginosus, and $H$. chlorostictus, described by Cardoso and Malabarba (1999) from southern Brazil near the type-locality of H. votouro and $H$. meizospilos, can be easily distinguished from the new species by having body, head, and fins, with dark dots $(H$. punctulatus), spotless (H. fuliginosus), and from $H$. chlorostictus by several body proportions already listed in the diagnosis section.
The results of the principal components analysis (PCA) revealed a complete separation between Hemiancistrus votouro, $H$. meizospilos, and $H$. chlorostictus along the second and third principal components (Fig. 7). With 6.3\% of total variation of data, $\mathrm{PC} 2$ contains the main shape differences between species. Characteristics loading strongly on PCA are adipose spine length $(0.71)$, width caudal peduncle $(0.20)$, and body depth at dorsal origin (-0.46) on second PC axe, and body depth at dorsal origin (0.36), orbit diameter (0.32), and dorsal spine length (-0.40) on third PC axis.

The ANCOVA including Hemiancistrus chlorostictus and $H$. votouro for adipose spine length as a function of $\mathrm{SL}$ $\left(F_{0,05(1,13)}=92.107, \mathrm{P}<0.000\right.$, fig. 2$)$ and length of exposed portion of cleithrum as a function of $\mathrm{SL}\left(F_{0,05(1,13)}=56.387, \mathrm{P}<0.000\right.$, fig. 3 ) were significantly different. The same test for orbit diameter as a function of HL, for Hemiancistrus meizospilos and $H$. votouro was also significantly different $\left(F_{0,05(1,23)}=58.908\right.$, $\mathrm{P}<0.000$, fig. 4).

Table 1. Morphometric and meristic characters for the holotype $(\mathrm{H})$ and paratypes of Hemiancistrus votouro $(\mathrm{n}=8)$ and Hemiancistrus meizospilos $(\mathrm{n}=27)$. Ranges include holotypes.

\begin{tabular}{|c|c|c|c|c|c|c|c|c|}
\hline \multirow[b]{2}{*}{ Character } & \multicolumn{4}{|c|}{ Hemiancistrus votouro } & \multicolumn{4}{|c|}{ Hemiancistrus meizospilos } \\
\hline & $\mathrm{H}$ & Low & High & Mean & $\mathrm{H}$ & Low & High & Mean \\
\hline Standard length (mm) & 133.9 & 99.5 & 141.2 & 124.6 & & 98.9 & 149.1 & 120.1 \\
\hline \multicolumn{9}{|l|}{ Percents of standard length } \\
\hline Head length & 33.0 & 32.6 & 35.0 & 33.6 & 31.7 & 31.6 & 35.9 & 33.5 \\
\hline Predorsal length & 42.9 & 41.2 & 44.4 & 42.9 & 41.4 & 39.6 & 46.9 & 42.0 \\
\hline Dorsal spine length & 30.2 & 26.5 & 30.2 & 29.0 & 26.3 & 23.2 & 28.5 & 25.5 \\
\hline Anal spine length & 11.1 & 10.1 & 12.4 & 11.3 & 10.4 & 9.2 & 12.1 & 10.4 \\
\hline Pectoral spine length & 39.8 & 36.2 & 41.3 & 38.4 & 35.1 & 31.4 & 37.5 & 34.4 \\
\hline Ventral spine length & 28.2 & 26.2 & 28.2 & 27.2 & 24.3 & 23.6 & 27.2 & 25.4 \\
\hline Adipose spine length & 10.4 & 9.0 & 10.4 & 9.8 & 8.7 & 7.7 & 10.1 & 9.0 \\
\hline Upper caudal spine length & 30.0 & 26.9 & 30.0 & 28.3 & 24.3 & 23.7 & 28.6 & 26.3 \\
\hline Lower caudal spine length & 33.9 & 29.2 & 34.0 & 32.0 & 27.7 & 26.2 & 34.0 & 30.1 \\
\hline Trunk length & 23.8 & 22.3 & 24.9 & 23.7 & 21.2 & 20.4 & 25.2 & 23.1 \\
\hline Abdominal length & 25.5 & 23.7 & 25.7 & 25.0 & 22.6 & 20.7 & 34.8 & 22.8 \\
\hline Length of exposed portion of cleithrum & 11.3 & 11.2 & 12.7 & 11.8 & 10.1 & 8.9 & 11.9 & 10.5 \\
\hline Cleithral width & 34.4 & 32.8 & 34.4 & 33.5 & 32.8 & 31.3 & 35.9 & 33.5 \\
\hline Body depth at dorsal origin & 19.2 & 17.9 & 19.8 & 18.8 & 20.9 & 16.3 & 25.5 & 20.9 \\
\hline Body width at anal origin & 19.9 & 17.0 & 19.9 & 17.9 & 18.9 & 17.3 & 20.3 & 18.6 \\
\hline Length caudal peduncle & 36.4 & 31.5 & 36.4 & 34.3 & 34.1 & 31.8 & 38.2 & 35.1 \\
\hline Depth caudal peduncle & 11.1 & 11.0 & 11.8 & 11.3 & 11.1 & 10.2 & 11.8 & 11.0 \\
\hline Width caudal peduncle & 7.3 & 5.6 & 7.3 & 6.4 & 7.1 & 5.4 & 7.4 & 6.3 \\
\hline \multicolumn{9}{|l|}{ Percents of head length } \\
\hline Snout length & 59.0 & 59.0 & 61.8 & 60.1 & 63.6 & 57.3 & 63.6 & 60.5 \\
\hline Orbital diameter & 16.1 & 14.5 & 16.7 & 15.7 & 18.1 & 16.7 & 20.1 & 18.2 \\
\hline Interorbital width & 31.9 & 31.6 & 34.1 & 32.7 & 34.0 & 29.1 & 34.0 & 31.9 \\
\hline Head depth & 52.9 & 46.3 & 53.7 & 50.1 & 52.6 & 48.3 & 56.3 & 51.7 \\
\hline Left premaxilla ramus length & 21.5 & 20.2 & 23.2 & 21.1 & 23.2 & 16.9 & 23.2 & 21.1 \\
\hline \multicolumn{9}{|l|}{ Counts } \\
\hline Left lateral plates & 25.0 & 24.0 & 25.0 & 24.6 & 25.0 & 25.0 & 25.0 & 25.0 \\
\hline Teeth on left premaxilla & 78.0 & 61.0 & 79.0 & 71.4 & 66.0 & 50.0 & 66.0 & 57.2 \\
\hline Teeth on left dentary & 75.0 & 61.0 & 84.0 & 71.8 & 67.0 & 48.0 & 67.0 & 58.4 \\
\hline Plates at dorsal-fin base & 8.0 & 8.0 & 8.0 & 8.0 & 8.0 & 6.0 & 8.0 & 7.6 \\
\hline Plates between dorsal and adipose fins & 5.0 & 5.0 & 6.0 & 5.4 & 5.0 & 5.0 & 6.0 & 5.5 \\
\hline Plates at anal-fin base & 2.0 & 2.0 & 3.0 & 2.5 & 2.0 & 2.0 & 2.0 & 2.0 \\
\hline
\end{tabular}


Vidal \& Lucena (1999) suggested the upper rio Uruguai as an area of endemism, and listed several species with their geographic range restricted to that basin (Leporinus amae Godoy; Oligosarcus brevioris Menezes; Pimelodus atrobrunneus Vidal \& Lucena; Hemipsilichthys vestigipinnis Pereira \& Reis; Eurycheilichthys pantherinus Reis \& Schaefer; Hypostomus luteus Godoy; Crenicichla igara Lucena \& Kullander, $C$. jurubi Lucena \& Kullander and $C$. prenda Lucena \& Kullander). Hemiancistrus chlorostictus and Pogonopoma obscurum Quevedo \& Reis, described latter are also endemic to the area. Now, the discovery of $H$. votouro and $H$. meizospilos adds further support to the hypothesis that the upper rio Uruguai basin is an area of endemism.

\section{Acknowledgements}

We are grateful Paulo H. F. Lucinda (UFT), Paulo A. Buckup (MNRJ), and Edson H. L. Pereira (MCP) for their comments and suggestions on the manuscript and to Sonia Fisch-Muller (MHNG) for providing e-mail discussions about Hemiancistrus macrops and H. megacephalus. We thank Vinicius A. Bertaco and Cíntia C. Kaefer for assistance in the collection. We are grateful Roberto B. Oliveira for the Statistical assistance. We thank the Universidade Regional do Alto Uruguai e Missões (URI) and Fundo Nacional do Meio Ambiente (FNMA) for financial support to the project "Plano de Gestão Ambiental da TI do Votouro/RS". Tiago Piccinin, Ivonir Artuso, and André Trevisan provided assistance during field work. JFPS is grateful to Willi Bruschi Jr. (Biolaw Consultoria Ambiental Ltda.) for the opportunity to participate in this project. We also thank Leandro Baucke and Alcione Cella, who first collected specimens $H$. meizospilos during their research on fishes from rio Chapecó system.

\section{Literature Cited}

Bertoletti, J. J., C. A. S. Lucena, Z. M. S. Lucena, L. R. Malabarba \& R. E. Reis. 1989. Ictiofauna do rio Uruguai superior entre os municípios de Aratiba e Esmeralda, Rio Grande do Sul, Brasil. Comunicações do Museu de Ciências e Tecnologia da PUCRS, Sér. Zool., 48: 3-42.
Bookstein, F. L., B. C. Chernoff, R. L. Elder, J. M. Humphries, G. S. Smith \& R. E. Strauss. 1985. Morphometrics in evolutionary biology. Special Publication Academic Science of the Philadelphia, 15: 1-277.

Cardoso, A. R. \& P. H. F. Lucinda. 2003. Three new species of Hemiancistrus (Teleostei: Siluriformes: Loricariidae) from the rio Tocantins basin with comments on the genus. Ichthyological Exploration of Freshwaters, 14(1): 73-84.

Cardoso, A. R. \& L. R. Malabarba. 1999. Description of three new species of Hemiancistrus Bleeker, 1862 from southern Brazil (Teleostei: Siluriformes: Loricariidae). Comunicações do Museu de Ciências e Tecnologia da PUCRS, Sér. Zool., 12: 141-161.

Fisch-Muller, S. 2003. Subfamily Ancistrinae. Pp.373-400 In: R. E. Reis, S. O. Kullander \& C. J. Ferraris, Jr. (eds.). Check List of the Freshwater Fishes of South and Central America. Edipucrs, Porto Alegre, 729p.

Jolicoeur, P. 1963. The multivariate generalization of the allometry equation. Biometrics, 19: 497-499.

Malabarba, L. R. 1989. Histórico sistemático e lista comentada das espécies de peixes de água doce do sistema da Laguna dos Patos, Rio Grande do Sul, Brasil. Comunicações do Museu de Ciências e Tecnologia da PUCRS, Sér. Zool., 2(8): 107-179.

Regan, C. T. 1904. A monograph of the fishes of the family Loricariidae. Transactions of the Zoological Society of London, 13(3): 191-350.

Vidal, E. S. \& C. A. S. Lucena. 1999. Pimelodus atrobrunneus, uma nova espécie de Pimelodíneo do rio Uruguai superior (Teleostei, Siluriformes, Pimelodidae). Biociências, Porto Alegre, 7(1): 121-134.
Received September, 2003 Accepted April, 2004 